\title{
HPA axis overactivity and the pathogenesis of depression
}

Jogin H Thakore, PhD, MRCPsych, Lecturer in Psychological Medicine, St Bartholomew's Hospital, London EC1A 7BE, England.

\section{Normal physiology of the HPA axis}

Neuro-endocrine systems are characterised by a feed forward limb, which results in the synthesis and release of hormones, and a negative feedback limb whereby these substances limit their own production. ${ }^{1}$ Corticotropin-releasing hormone ( $\mathrm{CRH})$ has the majority of its cell bodies in paraventricular nucleus of the hypothalamus and is under the regulation of hormonal, neuronal and neurochemical inputs. ${ }^{2}$ This neuropeptide is the most potent adrenocorticotropin (ACTH) secretagogue known and binds to specific membrane receptors on pituitary corticotropes. ACTH is responsible for promoting adrenal steroidogenesis and does so by acting at membrane specific adrenocortical receptors. ${ }^{3}$

Cortisol limits its own production by acting at a hypothalamic and pituitary level. ${ }^{4}$ Feedback inhibition is mediated by two types of corticosteroid receptors, Type 1 and Type 2. Mineralocorticoid or Type 1 receptors, are principally located in the septo-hippocampal complex, have a high affinity for cortisol and are believed to be involved with tonic inhibitory activity within the Hypothalamic-pituitary-adrenal (HPA) axis; glucocorticoid (GC) or Type 2 receptors have widespread distribution throughout the central nervous system, have a lower affinity for their substrate and appear to 'switch off' the production of cortisol during times of overactivity of the HPA axis.

\section{HPA axis function in depression}

Pathological overactivation of the HPA axis in patients with major depressive illness may reflect disruption of the feed-forward limb and/or the feedback limb. ${ }^{6}$ The fact that cerebrospinal fluid concentrations of $\mathrm{CRH}$ are increased in depressives ${ }^{7}$ suggests hyperactivity of the positive feedforward limb with the HPA axis. Furthermore, administration of ACTH to depressives leads to a greater release of cortisol in depressives than in normal controls. Dexamethasone administration in control subjects leads to a suppression of plasma cortisol levels; the same is not true of depression which suggest a malfunctioning negative feed- back system. ${ }^{8}$ HPA axis disturbances have hithertofore been considered as secondary to monoaminergic dysfunction in depression. However, the evidence from basic science and clinical studies for the contrary is just as convincing.

\section{Glucocorticoid-monoaminergic interactions}

A glucocorticoid milieu analogous to depression in humans can be simulated by exposing animals to high levels of corticosterone. Such animals display deficits in serotonergic-dependent cellular and behavioural activity which may offer insights into the possible pathogenesis of depression. Central serotonergic activity is responsible for stimulating the release of the anterior pituitary hormone, prolactin (PRL). ${ }^{10}$ Therefore, plasma levels of PRL indirectly reflect 5HT-dependent activity. A wealth of scientific literature exists regarding the effects of adrenal steroids on PRL release. Chronic exposure to glucocorticoids either in the form of persistent stress or exogenous corticosterone administration leads to a decrease in the number $5 \mathrm{HT}_{1}$ receptors in the hippocampus and raphe nuclei (neurones that contain the cell bodies of 5HT) and a decrease in PRL secretion. ${ }^{11-14}$ Furthermore, suckling-induced PRL secretion, hind-limb abduction, forepaw treading and head weaving, all 5HTdependent behaviours are markedly reduced in the presence of high levels of corticosterone. ${ }^{15,16}$

A similar interaction between GCs and serotonergic function has been reported in a human volunteer study ${ }^{17}$ examining the role of cortisol on spontaneous and 5HTmediated PRL release. Metyrapone (a steroid lowering agent) treatment of healthy controls resulted in enhanced dfenfluramine (D-FEN) (a serotonergic agonist) induced PRL secretion and an increase in the nocturnal surge of PRL. In the second part of the study, thyrotropin-mediated PRL secretion (a pituitary-dependent process) was augmented following metyrapone treatment, indicating that cortisolinduced inhibition of PRL release is partly mediated at a pituitary level.

From a clinical perspective, blunted prolactin release in

Editor-in-Chief: Brian A Lawlor (Dublin). Editors: Timothy Dinan (London), David King (Belfast). Deputy Edilor: Brian O'Shea (Dublin). Associate Editors: Ken Brown (Belfast), Patricia Casey (Dublin), Anthony Clare (Dublin), Stephen Cooper (Belfast), Thomas Fahy (Galway), Michael Fitzgerald (Dublin), Michael Kelleher (Cork), Brian Leonard (Galway), Roy McClelland (Belfast), Aidan McGennis (Dublin), Ciaran O'Boyle (Dublin), Eadbhard O'Callaghan (Dublin), Art O'Connor (Dublin), Ethna O'Gorman (Belfast), Ian Pullen (Edinburgh), David Sheehan (Tampa), Philip Snaith (Leeds), Hugh Staunton (Dublin), John Waddington (Dublin), Richard Williams (Calgary). Statistical Editor: Lesslie Daly (Dublin). Deputy Statistical Editor: Ronan Conroy (Dublin). 
response to a number of serotonergic agonists such as, D$\mathrm{FEN}^{18}$, d,1-fenfluramine ${ }^{19}$, L-tryptophan ${ }^{20}$ is a characteristic feature of depression. Strong evidence exists to indicate that high levels of cortisol may be responsible for reduced PRL release in depression. ${ }^{18,21}$ Therefore, from the animal and human data presented so far, hypercortisolaemic-induced serotonergic hyporesponsivity may be responsible for the affective and biological features observed in depression.

The presence of noradrenergic synapses on the CRHcontaining paraventricular neurones suggests the presence of significant interactions between the HPA and the noradrenergic system. ${ }^{22}$ In fact, adrenalectomy results in a decrease in the number of $\alpha 2$-nordrenergic receptors, a process prevented by corticosterone replacement. ${ }^{23}$ Suppression of noradrenergic-mediated cAMP (the principal second messenger involved with this receptor subclass) occurs in the cerebral cortex of rats exposed to adrenocorticoids. ${ }^{12} \mathrm{~A}$ recent in vivo study has added further weight to these observations in that glucocorticoids reduce basal and stress-induced catecholaminergic activity in the paraventricular nucleus, implying that noradrenergic neurones are sites for adrenocorticoid action. ${ }^{24}$

Despite evidence that noradrenergic activity is grossly disturbed in depression, ${ }^{25}$ there have been few if any studies examining the interaction between glucocorticoids and noradrenergic function in this condition. In health, stimulation of specific noradrenergic receptors results in the secretion of growth hormone from the anterior pituitary. Blunted desipramine/growth hormone responses are a characteristic feature of depressive illness, occurring more frequently in patients who show non-suppression to dexamethasone, indicating a link between abnormal functioning of the HPA axis and growth hormone secretion. ${ }^{26,27}$ It would appear that serotonergic activity and perhaps noradrenergic function may be abnormal in depression as a consequence of primary HPA axis disturbance.

\section{Affective disorder and excess glucocorticoids}

Neurotransmitter considerations aside, the administration of exogenous steroids has long been associated with psychiatric disturbance which can range from subtle personality changes, cognitive defects, dysphoria and elation to frank psychosis, with reported incidence of such adverse-effects varying from 1.8 to $57.0 \% .^{28-31}$ Over production of endogenous cortisol as in Cushing's syndrome can lead to psychiatric symptoms not unlike those found in depression. ${ }^{33}$

Dorn and his colleagues ${ }^{34}$ have provided us with one of the most detailed accounts of the psychiatric status of Cushing's syndrome patients. They found that $66.7 \%$ of their patients fulfiled DSM-IIIR criteria for various psychiatric diagnoses with half of these suffering from a major depressive disorder and longer duration of illness placing them at an increased rick of such psychopathology. Though the precise processes underpinning these disorders are unknown, glucocorticoids are known to affect neural activity and alter the activities of certain neurotransmitters. ${ }^{32}$ Reduction of ambient cortisol levels by surgery or pharmacotherapy leads to an amelioration of physical and psychiatric symptomatology in the majority of patients. ${ }^{35,36}$

These observations together with the fact that patients with major depression who have abnormal pre-treatment dexamethasone suppression tests are less likely to respond to placebo and that an an abnormal post-treatment result signifies a poor prognosis, have provided a major stimulus for using steroid lowering agents in patients with affective disorders. $^{37}$

\section{Antidepressant response and normalisation of HPA axis function}

Certain clinical studies have shown a close correlation between conventional antidepressant action and the normalisation of the HPA axis disturbances observed in depressive disorders. ${ }^{3841}$ As mentioned earlier, major depression is characterised by abnormal negative feedback, reflecting dysfunctional corticosteroid receptor function. Direct evidence of receptor defects has come from various investigators who have observed that Type 2 receptors are either not present in sufficient number or lack plasticity (ie: the ability to up and down regulate in response to differing steroid milieus) leading to a reduced capacity in 'switching off' the HPA axis. ${ }^{42}$

Experimental studies have shown that the effectiveness of traditional antidepressants may lie in their ability to manipulate the corticosteroid receptor milieu in major depression. Preclinical studies, using mostly in vitro preparations, indicate that antidepressants increase Type 1 and Type 2 receptor number thereby restoring negative feedback and allowing HPA axis homeostasis to be regained in depression. ${ }^{43}$ For instance, Montokowski et $a l^{44}$ have shown that treatment with conventional antidepressants can reduce many of the abnormalities found in transgenic mice that have impaired Type 2 receptor activity. Furthermore, the time course ( 3 weeks) of receptor changes paralleled the time frame within which patients respond to conventional antidepressant therapy.

From a clinical perspective, drugs with effects on the HPA axis have been used with some benefit in the treatment of major depressive disorder. The earliest series of studies was by Murphy and her colleagues. ${ }^{45,46}$ With trials lasting on average eight weeks, they used varying doses of either aminogluthemide, ketoconazole or metyrapone in treatment refractory patients and found response rates approaching $50 \%$. Wolkowitz et $\mathrm{al}^{47}$ used ketoconazole in hypercortisolaemic patients with major depression over a three to six week period and found that Hamilton Depression Rating Scale (HAMD) levels decreased by $30 \%$.

Thakore and Dinan ${ }^{48}$ used ketocanozole in non-refractory patients with major depressive disorder and found HAMD reductions of $63 \%$ and an increase in D-FEN-induced prolactin release, indicating an augmentation of serotonergic function. $\mathrm{O}^{\prime} \mathrm{D}$ wyer et $\mathrm{al}^{49}$ used metyrapone and placebo in a single-blind, cross-over paradigm and found a response rate of $63 \%$. However, their results are confounded by the fact that they used hydrocortisone in order to prevent hypadrenalism, potentially induced by metyrapone. Krishnan et al ${ }^{50}$ and Murphy et al ${ }^{\text {st }}$ using mifepristone had smaller response rates and a greater number of treatment discontinuations due to side-effects.

To-date no large, double-blind placebo-controlled study has been undertaken with steroid lowering agents in major depression. In contrast to the above mentioned studies, Arana and his colleagues ${ }^{52-54}$ have used either intravenous dexamethasone in an open fashion or oral dexamethasone in a randomised, double-blind placebo-controlled manner and found active treatment to be more effective than placebo. The exact mechanisms underlying dexamethasone's effectiveness are unknown; however, supraphysiological doses of dexamethasone as used by Arana et al ${ }^{52-54}$ may serve to 
'switch off' the HPA axis at either a hypothalamic or hippocampal site.

\section{Conclusions}

Hyperactivity of the HPA axis may be a core feature rather than an epiphenomenon of major depressive illness. Many of the deficits in serotonergic and noradrenergic activity observed in depression could be secondary to HPA axis overactivity. Furthermore, classical antidepressant treatments upregulate brain glucocorticoid receptors and normalise HPA dysfunction. For these reasons, the development of drugs that directly or indirectly modulate glucocorticoid receptor function could provide exciting and novel strategies for the treatment of depression.

\section{References}

1. Houk JC. Control strategies in physiological systems. FASEB J 1988; 2:97-107. 2. Koob GF, Bloom FE. Corticotropin-releasing factor and behaviour. FASEB $1985 ; 44: 259-63$.

3. Farese RV. Phosphoinositide metabolism and hormone action. Endocr Rev 1983; 4: 78-95.

4. Dallman M, Akana SF, Scibner KA, et al. Stress, feedback and facilitation in the hypothalamo-pituitary adrenal axis. J Neuroendocrinol 1992; 4: 517-26.

5. De Kloet ER, Reul JM. Feedback action and tonic influence of corticosteroids on brain function: a concept arising from the heterogeneity of brain receptor systems. Psychoneuroendocrinol 1987; 12: 83-105.

6. Dinan TG. Glucocorticoids and the genesis of depressive illness: a psychobiolgocial model. Br J Psychiatry 1994; 164: 365-71.

7. Nemerhoff CB, Widerlov E, Bissette G, et al. Elevated concentrations of corticotropin releasing factor like immunoreactivity in depressed patients. Science 1984: 226: $1342-4$

8. Gold PW, Goodwin FK, Chrousos GP. Clinical and biochemical manifestations of depression: relation to the neurobiology of stress (second of two parts). N Engl J Med 1986: 319: 413-20.

9. Trimble MR. Biological Psychiatry. Chichester: Wiley, 1988: 241-81.

10. Van der Kar LD, Brownfield MS. Serotonergic neurons and neuroendocrine function. N Pharmacol Sci 1993; 8: 202-7.

11. Osestram Q, Verleunt T, Zuiderwijk J, et al. Effect of long term corticosteroid administration on rat pituitary growth hormone and prolactin. Act Endocrinologica 1985; 108: 475-8.

12. De Kloet ER, Sybesma H, Reul HMHM. Selective control of serotonin receptor capacity in raphe-hippocampal system. Neuroendocrinology 1986; 42 : 513-21.

13. Lopez-Calderon A, Ariznavarreta C. Calderon MD, et al. Role of the adrenal cortex in chronic stress-induced inhibition of prolactin secretion in rats. J Endocrinol 1989; 120: 269-73.

14. Di Scullio A, Bluet MT, Mounier P, et al. Changes in anterior pituitary levels after serotonin 1A receptor stimulation. Endocrinology 1990; 127: 567-572.

15. Dickinson SL, Kennett GA, Cruzon G. Reduced 5-hydroxytryptaminedependent behaviour in rats following chronic corticosterone treatment. Brain Res 1985; 345: 10-8

16. Bagdy G, Calogero AE, Aulakh CS, et al. Longterm cortisol treatment impairs behavioural and neuroendocrine responses to $5-\mathrm{HTl}$ agonists in the rat. Neuroendocrinology 1989; 50: 241-7.

17. Dinan TG. The role of cortisol in spontaneous and stimulated prolactin release J Basic Clin Physiol Pharmacol (in press).

18. O' Keane V, Dinan TG. Prolactin and cortisol responses to $\mathrm{d}$-fenfluramine in major depression: evidence for dimished reponsivity of central serotonergic function. Am J Psychiatry 1991; 148: 1009-15.

19. Siever LJ, Murphy D, Slater S, et al. Plasma prolactin following fenfluramine in depressed patients compared to controls: an evaluation of central serotonergic responsivity in depression. Life Sci 1984; 34: 1029-39.

20. Heninger GR, Charney DS, Sternberge DE. Serotonergic function in depression. Arch Gen Psychiatry 1984; 41: 398-402.

21. Mitchell P, Smythe G. Hormonal responses to fenfluramine in depressed and control subjects. J Affect Dis 1990; 19: 43-51.

22. Liposits Z. Phelix C. Paull WK. Synaptic interactions of serotonergic axons and corticotropin-releasing factor synthesising neurons in the hypothalamic paraventricular nucleus of the rat. Histochemistry 1987; 86: 541 -9.

23. Jhanwar-Uniyal M, Liebowitz SF. Impact of circulating corticosterone on alpha-1 and alpha-2 noradrenergic receptors in discrete brain areas. Brain Res 1986; 368: 404-8.

24. Pacak K, Palkovits M, Kvetnansky R, et al. Catecholaminergic inhibition by hypercortisolaemia in the paraventricular nucleus of the conscious rat Endocrinology 1995; 136: 4814-19
25. Coupland N, Glue P, Nutt DJ. Challenge tests: assessment of the noradrenergic and GABA systems in depression and anxiety disorders. 1992 Mol Asp Med; 13: 221-47.

26. Katona CLE, Theodorou AE, Davies SI, et al. Platelet binding and neuroendocrine responses in depression. In: Deakin JFW, editor. The biology of depression. London: Gaskell, 1986.

27. Dinan TG, Barry S. Responses of growth hormone to desipramine in endogenous and non-endogenous depression. Br J Psychiatry 1990; 156: 680-4.

28. Boston Collaborative Drug Surveillance Program. Acute adverse reactions to prednisone in relation to dosage. Clin Pharmacol Ther 1972; 13:694-8.

29. Hall CRW, Popkin MK, Stickney SK et al. Presentation of the steroid psychosis. J Nerv Ment Dis 1979; 167: 229-36.

30. Smyllie HC, Connolly CK. Incidence of serious complications of corticosteroid theapy in respiratory disease. Thorax $1968 ; 23: 571-8$.

31. Wolkowitz OM, Rubinow D, Doran AR, et al. Prednisone effects on neurochemistry and behaviour. Arch Gen Psychiatry 1990; 47: 963-8.

32. Murphy BEP. Steroids and depression. J Steroid Biochem Molec Biol 1991; 38: $537-59$

33. Dorn LD, Burgess ES, Dubbert B et al. Psychopathology in patients with endogenous Cushing's syndrome: 'atypical' or melancholic features ? Clin Endocrinol 1995; 43: 433-42.

34. De Kloet ER. Brain corticosteroid receptor balance and homeostatic control. Front Neuroendocrinol 1992; 12: 95-164.

35. Jeffcoate WJ, Silverstone TJ, Edwards CRW, et al. Psychiatric manifestations of Cushing's syndrome: response to lowering of plasma cortisol. Quart J Med 1979; 48: 465-72.

36. Starkman MN, Scheingart DE, Schork MA. Cushing's syndrome after treatment; changes in cortisol and ACTH levels, and amelioration of the depressive syndrome. Psychiatry Res 1986; 17: 177-88.

37. Ribeiro SCM, Tandon R, Grunhaus L, et al. The DST as a predictor of outcome in depression: a meta-analysis. Am J Psychiatry 1993; 150: 1618-29.

38. Holsboer-Trachsler E, Stohler R, Hatzinger M. Repeated administration of the combined dexamethasone/hCRH stimulation test druing the treatment of depression. Psychiatry Res 1991: 38: 163-71.

39. Holsboer-Trachsler E, Hemmeter U. Hatzinger M, et al. Sleep and bright light as potential augmenters of antidepressant drug treatment, neurobiological and psychometric assessment of course. J Pscyhiatry Re 1994; 28: 381-99.

40. Thakore JH, Dinan Tg. Cortisol synthesis inhibion: a new treatment strategy for the clinical and endocrine manifestations of depression. Biol Psychiatry 1995; 37: 364-8.

41. Rubin RT, Phillips JJ, Sadow TF, et al. Adrenal Gland volume in major depression: increase during the depressive episode and decrease with successful treatment. Arch Gen Psychiatry 1995; 52: 213-8.

42. Dinan TG. Glucocorticoids and the genesis of depressive illness: a psychobiological model. Br J Psychiatry 164: 365-71.

43. Barden N, Reul JMHM, Holsber F. Do antidepressants stabilise mood through actions on the hypothalamic-pituitary-adrenocoritcal system ? Trends Neursci 195; 18: 6-11.

44. Montokowski A, Barden N, Wotjak C, et al. Longt-term antidepressant treatment reduces behavioural deficits in transgenic mice with impaired glucocorticoid receptor function. Neuroendocrinol 1995; 7: 841-845.

45. Murphy BEP. Dhar V, Ghadirian Am, et al. Response to steroid suppression in major depression resistant to antidepressant therapy. J Clin Psychopharmacol 1991; 11: $121-6$.

46. Murphy BEP. Treatment of major depression with steroid suppressive drugs. J Steroid Biochem Molec Biol 1991; 39: 239-44.

47. Wolkowitz OM, Reus VI, Manfredi F, et al. Ketoconazole administration in hypercortisolaemic patients. Am J Psychiatry 1993; 150: 810-12.

48. Thakore JH, Dinan TG. Effect of fluoxetine on dexamethasone-induced growth hormone responses in depression: a double-blind placebo-controlled study. Am J Psychiatry $1995 ; 152: 616-8$

49. O'Dwyer AM, Lightman S, Marks MN, et al. Treatment of major depression with metyrapone and hydrocortisone. J Affect Disord 1995; 33: 123-8.

50. Krishnan KRR, Reed D, Wilson WH et al. RU486 in depression. Prog NeuroPsychopharmacol Biol Psychiatry 1992; 16: 913-20.

51. Murphy BEP, Filipini D, Gharidian AM. Possible use of glucocorticoid receptor antagonists in the treatment of major depression: preliminary results using RU486. J Psychiatry Neurosci 1993; 18: 209-13.

52. Arana GW. Intravenous dexamethasone for symptoms of major depressive disorder. Am J Psychiatry (letter) 1991; 10: 1401-2.

53. Arana GW, Forbes R. Dexamethasone for the treatment of depression: a preliminary report. J Clin Psychiatry 1991; 52: 304-6.

54. Arana GW, Santos AB, Laraia MT, et al. Dexamethasone for the treatment of depression: a randomized, placebo-controlled, double-blind trial. Am J Psychiatry $1995 ; 152: 265-7$

Original manuscript received November 1, 1995.

Final revision accepted February 10, 1996. 